\title{
Phocaeicola abscessus gen. nov., sp. nov., an anaerobic bacterium isolated from a human brain abscess sample
}

\author{
Mouhamad Al Masalma, Didier Raoult and Véronique Roux \\ Laboratoire de Bactériologie-Virologie, Hôpital de la Timone, URMITE CNRS-IRD UMR6236, \\ IFR48, 264 rue Saint-Pierre, 13385 Marseille, Cedex 05, France
}

Correspondence

Véronique Roux

vroux91@hotmail.com
Culture-independent approaches using 16S rRNA gene sequence clone library studies have demonstrated that approximately $50 \%$ of clones obtained from human oral cavity samples and $62-75 \%$ of clones obtained from human faecal and intestinal samples represent novel phylotypes (Aas et al., 2005; Hayashi et al., 2002; Eckburg et al., 2005). Studies based on $16 \mathrm{~S}$ rRNA gene sequence comparisons have demonstrated that many uncultured bacteria are implicated in human infections (Fredricks et al., 2005; Saito et al., 2006). Anaerobic bacteria are part of the normal human microbiota and play an important role in the regulation of the immune system and nutrient processing (Hooper \& Gordon, 2001), but they are also implicated frequently in human infections. Gram-positive anaerobic bacteria are classified in the phyla Firmicutes and Actinobacteria. Gram-negative anaerobic bacteria are most frequently clustered in the phylum Bacteroidetes. On the basis of heterogeneity, Shah \& Collins (1988, 1989, 1990) divided the genus Bacteroides into three genera: (i) Bacteroides, consisting of saccharolytic, non-pigmented species; (ii) Prevotella, consisting of moderately saccharolytic, bile-sensitive species; and (iii) Porphyromonas, generally consisting of asaccharolytic, black-pigmented species. Currently, the class 'Bacteroidia' includes four

The GenBank/EMBL/DDBJ accession number for the $16 \mathrm{~S}$ rRNA gene sequence of Phocaeicola abscessus strain $7401987^{\top}$ is EU694176.

16S rRNA gene sequence similarities between strain $7401987^{\top}$ and members of some of the most closely related genera are available as supplementary material with the online version of this paper. families, Bacteroidaceae, 'Porphyromonadaceae', 'Prevotellaceae' and 'Rikenellaceae'; members are obligately anaerobic, Gram-negative, non-sporulating, pleomorphic rods.

In this report, isolation of a novel Gram-negative anaerobic bacterium from a human brain abscess sample is described. Based on 16S rRNA gene sequence comparisons and biochemical and chemotaxonomic analyses, our isolate represents a novel species in a new genus that is distantly related to members of the genera Bacteroides, Parabacteroides, Prevotella, Porphyromonas, Tannerella and Dysgonomonas.

A 76-year-old woman underwent neurosurgical intervention after cancer of the face. Over a period of 3 days, she developed fever, consciousness alterations and aphasia. Magnetic resonance imaging and computerized tomography revealed a left frontal brain abscess with oedema. One day later, the patient underwent drainage of the abscess. A pus specimen recovered from the patient was sent to our laboratory in aerobic and anaerobic BACTEC blood culture bottles for culture and molecular investigations.

Supernatant from anaerobic BACTEC bottles was inoculated into Schaedler broth supplemented with K3 (bioMérieux). To eradicate rapidly growing bacteria that would outgrow anaerobes, liquid medium was supplemented with antibiotics. Four tube types were prepared: the first tube was supplemented with 0.0075 g vancomycin $1^{-1}$; the second tube was supplemented with $0.10 \mathrm{~g}$ kanamycin 
$1^{-1}$; the third tube was supplemented with both vancomycin and kanamycin; and no antibiotic was added to the fourth tube. Tubes were incubated at $37{ }^{\circ} \mathrm{C}$ and examined daily for bacterial growth. When the media were turbid, they were used to inoculate $5 \%$ sheep blood agar and chocolate agar plates (bioMérieux), which were then incubated anaerobically at $37{ }^{\circ} \mathrm{C}$. Plates were inspected every 5 days. Strain $7401987^{\mathrm{T}}$ was recovered after 10 days incubation under anaerobic conditions at $37^{\circ} \mathrm{C}$ from chocolate agar that had been inoculated with a sample from the kanamycin-supplemented tube.

Growth was tested on chocolate agar, $5 \%$ blood agar, tryptic soy agar and $5 \%$ blood Schaedler agar (bioMérieux). Growth was positive only on chocolate agar plates after 5 days incubation; growth was not observed after 15 days on the other media tested. Surface colonies on chocolate agar after 7 days incubation at $37{ }^{\circ} \mathrm{C}$ under anaerobic conditions were white, circular, regular, smooth, shiny, convex and $1 \mathrm{~mm}$ in diameter. Growth was also tested in BYP medium developed in our laboratory. The composition of the medium was as follows: brain-heart infusion agar $\left(10 \mathrm{~g} \mathrm{l}^{-1}\right)$, yeast extract $\left(10 \mathrm{~g} \mathrm{l}^{-1}\right)$, meat peptone $\left(5 \mathrm{~g} \mathrm{l}^{-1}\right)$, casein peptone $\left(5 \mathrm{~g} \mathrm{l}^{-1}\right)$, starch $(2 \mathrm{~g}$ $\left.\mathrm{l}^{-1}\right)$, D-glucose $\left(2.5 \mathrm{~g} \mathrm{l}^{-1}\right), \mathrm{NaCl}\left(2.5 \mathrm{~g} \mathrm{l}^{-1}\right), \mathrm{KH}_{2} \mathrm{PO}_{4}(1 \mathrm{~g}$ $\left.\mathrm{l}^{-1}\right), \mathrm{Na}_{2} \mathrm{HPO}_{4}\left(3 \mathrm{~g} \mathrm{l}^{-1}\right)$, haemin $\left(0.025 \mathrm{~g} \mathrm{l}^{-1}\right)$, vitamin $\mathrm{K}_{1}$ $\left(0.01 \mathrm{~g} \mathrm{l}^{-1}\right)$ and a vitamin/mineral mixture comprising vitamin $\mathrm{A}\left(500 \mathrm{IU} \mathrm{l}^{-1}\right)$, vitamin $\mathrm{D}_{3}\left(40 \mathrm{IU} \mathrm{l}^{-1}\right)$, vitamin $\mathrm{B}_{1}$ $\left(2 \mathrm{mg} \mathrm{l}^{-1}\right)$, vitamin $\mathrm{B}_{2}\left(2 \mathrm{mg} \mathrm{l}^{-1}\right)$, vitamin $\mathrm{B}_{6}(0.2 \mathrm{mg}$ $\left.\mathrm{l}^{-1}\right)$, vitamin $\mathrm{B}_{12}\left(0.6 \mathrm{mg} \mathrm{l}^{-1}\right)$, vitamin $\mathrm{B}_{3}\left(2 \mathrm{mg} \mathrm{l}^{-1}\right)$, vitamin $\mathrm{C}\left(6 \mathrm{mg} \mathrm{l}^{-1}\right)$, vitamin $\mathrm{E}\left(5 \mathrm{mg} \mathrm{l}^{-1}\right)$, folic acid $\left(0.3 \mathrm{mg} \mathrm{l}^{-1}\right)$, calcium pantothenate $\left(3 \mathrm{mg} \mathrm{l}^{-1}\right)$, iron (ferrous fumarate; $1.5 \mathrm{mg} \mathrm{l}^{-1}$ ), magnesium sulfate $\left(0.5 \mathrm{mg} \mathrm{l}^{-1}\right)$ and calcium phosphate $\left(10 \mathrm{mg} \mathrm{l}^{-1}\right)$. Growth was positive in this medium after 5 days incubation at $37{ }^{\circ} \mathrm{C}$ in an anaerobic atmosphere. Growth of the isolate was tested under anaerobic and microaerophilic conditions generated with the GENbag anaer and GENbag microaer systems, respectively (bioMérieux). Growth was also tested in the presence of air and 5\% $\mathrm{CO}_{2}$. The strain was strictly anaerobic and did not grow in air, $5 \% \mathrm{CO}_{2}$ or microaerophilic atmospheres. Different growth temperatures $\left(25,30,37,45\right.$ and $\left.50{ }^{\circ} \mathrm{C}\right)$ were tested; growth occurred between 30 and $37^{\circ} \mathrm{C}$. Optimum growth was observed at $37{ }^{\circ} \mathrm{C}$.

The size and ultrastructure of the cells were determined by transmission electron microscopy. Cells were grown on Schaedler broth for 7 days. A bacterial suspension was prefixed in $5 \%(\mathrm{v} / \mathrm{v})$ glutaraldehyde in phosphate buffer (Gibco) for at least $1 \mathrm{~h}$ at room temperature, washed in the same buffer and stained with $1 \%(\mathrm{w} / \mathrm{v})$ phosphotungstic acid. Samples were examined on a Morgagni 268D (Philips) electron microscope at an operating voltage of $60 \mathrm{kV}$. Coccoid and rod-shaped bacteria were observed. After 7 days growth in Schaedler broth, $7 \%$ cells were rods (1.7-0.4 $\mu \mathrm{m}$ wide and $1.2-6.5 \mu \mathrm{m}$ long) and $93 \%$ cells were coccoid $(0.3-0.6 \mu \mathrm{m}$ wide and $0.4-0.9 \mu \mathrm{m}$ long) (Fig. 1). Catalase activity, determined by the ID colour
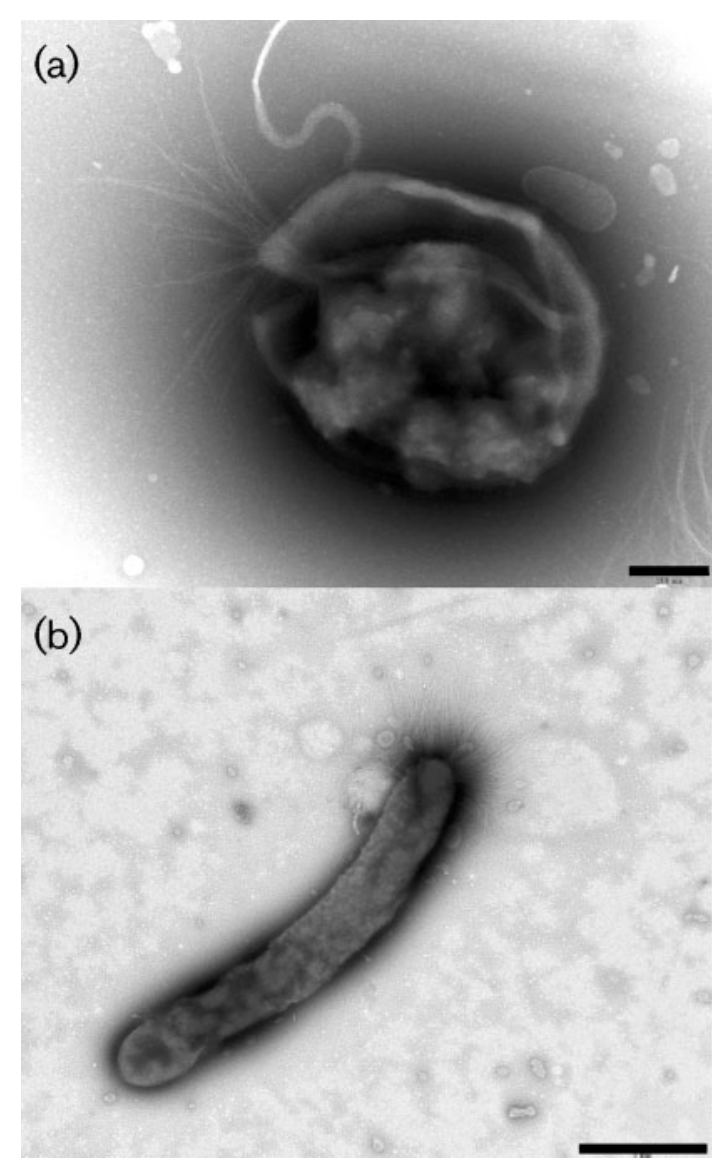

Fig. 1. Transmission electron micrographs of cells of strain $7401987^{\top}$. The lophotrichous flagellar arrangement is noted in the coccoid ( $a$; bar, $200 \mathrm{~nm}$ ) and rod (b; bar, $1 \mu \mathrm{m})$ forms.

catalase test kit (bioMérieux), was negative. Oxidase activity was negative as determined by applying cells to moistened discs that were impregnated with dimethyl- $p$ phenylene diamine (bioMérieux). A mobility test, performed after 8 days incubation in Schaedler broth, was positive. API ZYM, API Rapid ID 32A and API 50CH strips combined with API 50CHB/E (all bioMérieux) were used for biochemical tests according to the manufacturer's instructions. Additional biochemical characteristics were also obtained using the Biolog system. Bacterial growth was observed on chocolate agar plates (bioMérieux) and cells were suspended in AN inoculation fluid sterile (Biolog) to a density of 0.35 and transferred to AN Microplates (Biolog) as described by the manufacturer. Incubation was carried out at $37{ }^{\circ} \mathrm{C}$ under an anaerobic atmosphere for $24 \mathrm{~h}$. Acid was not produced from any of the carbohydrates tested. Results for strain $7401987^{\mathrm{T}}$ are given in the species description.

Resistance to bile was verified by growing the bacteria on BYP medium supplemented with $2 \%(\mathrm{w} / \mathrm{v})$ dehydrated gall salt (bile sac powder; MP Biomedicals) equivalent to $20 \%$ $(\mathrm{v} / \mathrm{v})$ bile. The strain was susceptible to bile. 
Preparation and determination of cellular fatty acids were carried out by following a highly standardized method similar to the Sherlock Microbial Identification system (MIDI). The major cellular fatty acids were anteiso- $\mathrm{C}_{15: 0}$ $(28.2 \%), \mathrm{C}_{16: 0}(18.0 \%)$, iso- $\mathrm{C}_{15: 0}(12.3 \%)$, iso- $\mathrm{C}_{17: 0} 3-$ $\mathrm{OH}(11.7 \%)$, a mixture of $\mathrm{C}_{18: 2} \omega 6,9 c$ and anteiso- $\mathrm{C}_{18: 0}$ (6.7\%), $\mathrm{C}_{15: 0}(6.2 \%), \mathrm{C}_{16: 0} 3-\mathrm{OH}(4.4 \%), \mathrm{C}_{18: 0}(3.0 \%)$, $\mathrm{C}_{18: 1} \omega 9 c(2.5 \%)$ and $\mathrm{C}_{17: 0} 3-\mathrm{OH}(2.1 \%)$.

Differential characteristics of strain $7401987^{\mathrm{T}}$ and some related taxa are shown in Table 1.

Matrix-assisted laser-desorption/ionization time-of-flight (MALDI-TOF) MS protein analysis was carried out. A smear of bacterial material was deposited on each spot of a polished-steel target plate. After air-drying, $1.5 \mu \mathrm{l}$ matrix solution (saturated solution of $\alpha$-cyanohydroxycinnaminic acid in $50 \%$ aqueous acetonitrile containing $2.5 \%$ trifluoroacetic acid) per spot was applied. MALDI-TOF MS was conducted using the Autoflex II MS (Bruker Daltonics). All spectra were recorded in linear, positive-ion mode. The acceleration voltage was $20 \mathrm{kV}$. Spectra were collected as a sum of 675 shots across a spot. The manipulation was repeated six times. Preprocessing and identification steps were performed using the manufacturer's parameters. Spectra were compared with the existing bank in the BIOTYPER software. No significant score was obtained, thus confirming that our isolate was not a member of a known species and, potentially, was not a representative of any known genus. A consensus spectrum was produced and a taxonomic tree was obtained by the principal component analysis clustering method (Fig. 2).

Bacterial DNA was extracted using the MagNA Pure LC DNA isolation kit III (Roche) with the MagNA Pure LC instrument as described by the manufacturer. The $16 \mathrm{~S}$ rRNA gene of the isolated strain was amplified by PCR using the universal primer pair $\mathrm{fD} 1$ and $\mathrm{rp} 2$ (Weisburg et al., 1991). The amplified products were purified using the NucleoFast 96 PCR kit (Macherey-Nagel) according to the manufacturer's recommendations. A BigDye Terminator cycle sequencing kit (Applied Biosystems) and ABI PRISM 3130X Genetic Analyzer (Applied Biosystems) were used for sequencing according to the manufacturer's instructions. The different fragments were assembled using SEQUENCHER software (Applied Biosystems). The sequence obtained was compared with those in GenBank by using BLAST through the NCBI server and similarities were determined. Gene sequences were aligned using the multisequence alignment program CLUSTAL_X version 1.8 . Phylogenetic relationships with closely related species were determined using MEGA version 4 (Tamura et al., 2007). Distance matrices were determined following the assumptions described by Kimura (1980) and were used to elaborate dendrograms using the neighbour-joining method (Saitou \& Nei, 1987). The maximum-parsimony algorithm was also used to infer phylogenetic relationships. A bootstrap analysis was performed to investigate the stability of the tree obtained. Bootstrap values were obtained for a consensus tree based on 100 randomly

Table 1. Differential characteristics of strain $7401987^{\top}$ (Phocaeicola abscessus gen. nov., sp. nov.) and some related genera

Reference genera: 1, Bacteroides (data from Shah \& Collins, 1989); 2, Prevotella (Willems \& Collins, 1995a); 3, Dysgonomonas (Hofstad et al., 2000); 4, Porphyromonas (Willems \& Collins, 1995b); 5, Parabacteroides (Sakamoto \& Benno, 2006); 6, Tannerella (Sakamoto et al., 2002). +, Positive; -, negative; v, variable; ai-, anteiso-branched; i-, iso-branched.

\begin{tabular}{|c|c|c|c|c|c|c|c|}
\hline Characteristic & Strain $7401987^{\mathrm{T}}$ & 1 & 2 & 3 & 4 & 5 & 6 \\
\hline Growth in bile & - & + & - & + & - & + & - \\
\hline Aerobic growth & - & - & - & + & - & - & - \\
\hline Mobility & + & - & - & - & - & - & - \\
\hline Pigment & - & - & $\mathrm{v}$ & - & $+^{*}$ & - & - \\
\hline Catalase production & - & $\mathrm{v}$ & $\mathrm{v}$ & $\mathrm{v}$ & $\mathrm{V}$ & $\mathrm{V}$ & $\mathrm{V}$ \\
\hline Aesculin hydrolysis & - & $\mathrm{v}$ & $\mathrm{v}$ & $\mathrm{v}$ & - & + & + \\
\hline Indole production & - & $\mathrm{v}$ & $\mathrm{v}$ & $\mathrm{v}$ & $\mathrm{v}$ & - & $\mathrm{V}$ \\
\hline Nitrate reduction & - & - & - & - & - & - & + \\
\hline $\begin{array}{l}\text { Optimum growth } \\
\text { temperature }\left({ }^{\circ} \mathrm{C}\right)\end{array}$ & 37 & 37 & 37 & 35 & 37 & 37 & 37 \\
\hline Time for visible growth & 7 days & $48 \mathrm{~h}$ & $48 \mathrm{~h}$ & $48 \mathrm{~h}$ & $48 \mathrm{~h}$ & $48 \mathrm{~h}$ & $48 \mathrm{~h}$ \\
\hline $\begin{array}{l}\text { Major cellular fatty } \\
\text { acids }\end{array}$ & $\begin{array}{c}\text { ai- } C_{15: 0}, C_{16: 0}, \\
\text { i- } C_{15: 0}, i-C_{17: 0} \\
3-O H\end{array}$ & $\begin{array}{c}\text { ai- } \mathrm{C}_{15: 0} \\
\mathrm{i}-\mathrm{C}_{17: 0} 3-\mathrm{OH}, \\
\mathrm{i}-\mathrm{C}_{15: 0}, \mathrm{C}_{16: 0}\end{array}$ & $\begin{array}{c}\text { ai- } \mathrm{C}_{15: 0}, \\
\mathrm{i}-\mathrm{C}_{17: 0} 3-\mathrm{OH}, \\
\mathrm{i}-\mathrm{C}_{15: 0}, \mathrm{C}_{16: 0}\end{array}$ & $\begin{array}{c}\text { ai- } C_{15: 0}, C_{16: 0} \\
\text { i- } C_{14: 0}, C_{16: 0} \\
3-O H\end{array}$ & $\begin{array}{l}\text { ai- } C_{15: 0} \\
\quad \text { i- } C_{15: 0}\end{array}$ & $\begin{array}{c}\text { ai- } \mathrm{C}_{15: 0} \\
\mathrm{i}-\mathrm{C}_{17: 0} 3-\mathrm{OH}, \\
\mathrm{C}_{18: 1} \omega 9 c, \mathrm{i}-\mathrm{C}_{15: 0}\end{array}$ & $\begin{array}{r}\text { ai- } \mathrm{C}_{15: 0}, \mathrm{C}_{16: 0} \\
3-\mathrm{OH}, \mathrm{i}-\mathrm{C}_{17: 0} \\
3-\mathrm{OH}, \mathrm{C}_{16: 0}\end{array}$ \\
\hline Metabolism $\dagger$ & NF & $\mathrm{F}$ & MF & $\mathrm{F}$ & $\mathrm{NF}$ & $\mathrm{F}$ & $\mathrm{NF}$ \\
\hline Principal source & Brain abscess & Faeces & Oral cavity & $\begin{array}{c}\text { Human clinical } \\
\text { specimens }\end{array}$ & Oral cavity & Faeces & $\begin{array}{c}\text { Periodontal } \\
\text { pockets }\end{array}$ \\
\hline
\end{tabular}

*Porphyromonas catoniae does not produce a black pigment on blood agar.

$\dagger F$, Fermentative; MF, moderately fermentative; NF, non-fermentative. 


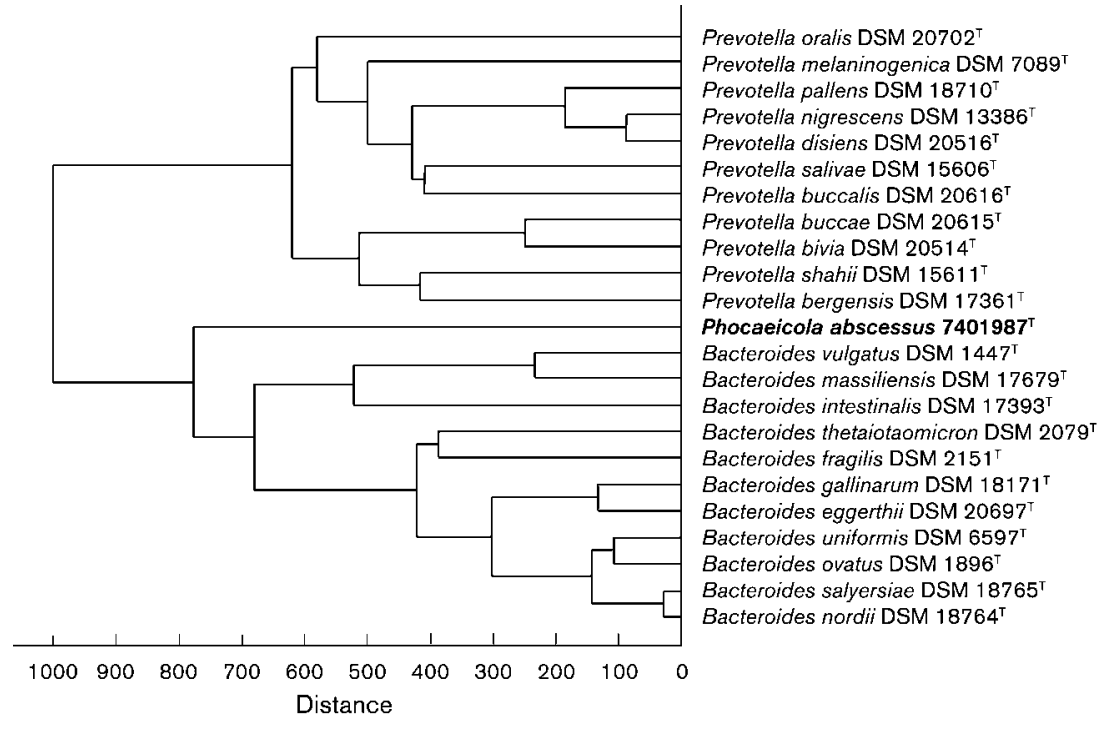

Fig. 2. Mean spectra projection (MSP) dendrogram generated by BIOTYPER software (version 2; Bruker Daltonics) showing the similarity of MALDI-TOF mass spectra of strain $7401987^{\top}$ and representatives of the genera Bacteroides and Prevotella. generated trees. The tree organization was the same using the two methods (Fig. 3).

The 16S rRNA gene sequence of strain $7401987^{\mathrm{T}}$ showed similarities of $99.6,99.8,99.9,99.6$ and $99.6 \%$ to sequences of five previously described uncultured bacteria (GenBank accession nos AM419955, AF481203, AY005066, EF192781 and DQ633518, respectively) from noma patients, endodontic infection, subgingival plaque, dental implants and diseased distal oesophagus, respectively.

$16 \mathrm{~S}$ rRNA gene sequence comparisons revealed that strain $7401987^{\mathrm{T}}$ was distantly related to members of the genus Bacteroides (the most closely related type strain was
Bacteroides vulgatus ATCC $8482^{\mathrm{T}}$, with $83.6 \%$ similarity). All 16S rRNA gene sequences from known species from the genus Bacteroides were retrieved from GenBank. These sequences were aligned with the newly determined sequence of strain $7401987^{\mathrm{T}}$ and sequence similarity values were determined by using the program BIOEDIT (Hall, 1999). Similarities ranged from $83.6 \%$ with B. vulgatus ATCC $8482^{\mathrm{T}}$ to $68.3 \%$ with Bacteroides coagulans ATCC $29798^{\mathrm{T}}$. Similarity values were determined between strain $7401987^{\mathrm{T}}$ and the most closely related members of the genera Porphyromonas, Prevotella, Dysgonomonas, Tannerella, Anaerophaga and Parabacteroides and are presented in Supplementary Table S1 (available in IJSEM Online).

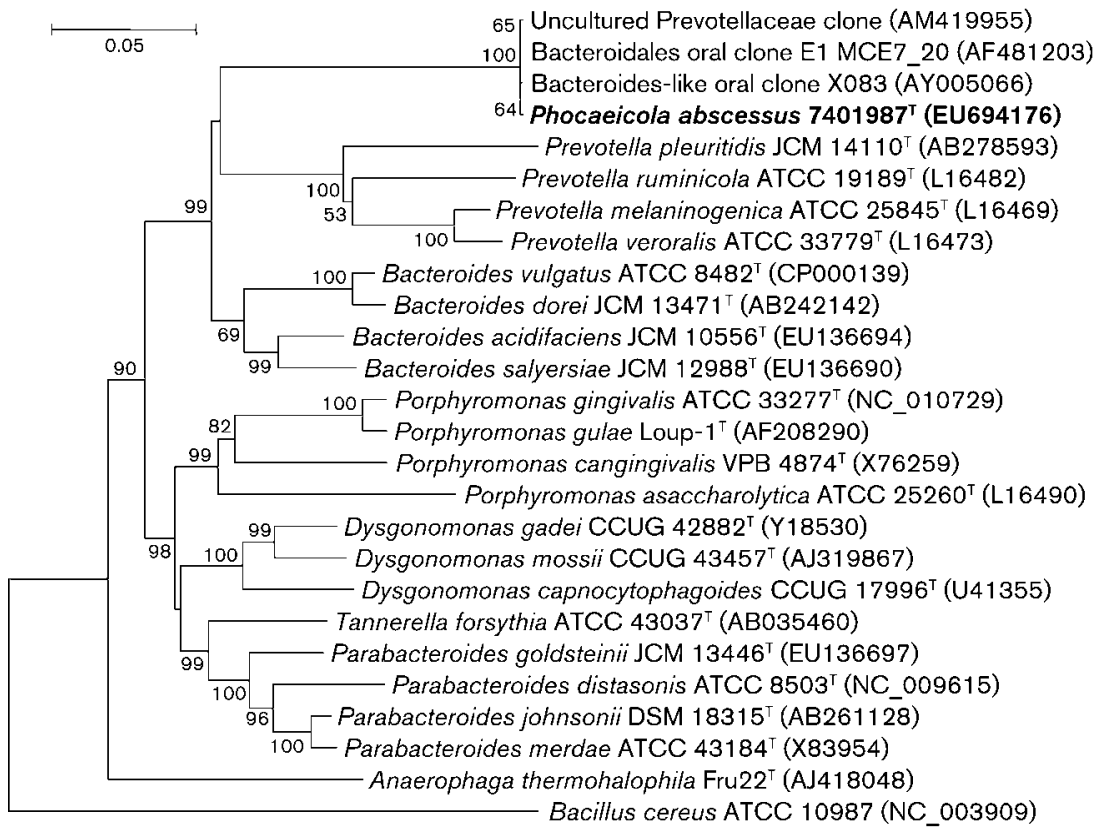

Fig. 3. Phylogenetic tree showing the position of Phocaeicola abscessus $7401987^{\top}$ within the 'Bacteroidales'. The tree was constructed by using the neighbour-joining method based on 16S rRNA gene sequences (1425 nt fragment). Numbers at nodes are proportions of 100 resamplings that support the topology shown; bootstrap values $>50 \%$ are indicated. The sequence of Bacillus cereus ATCC 10987 was used as the outgroup. Bar, 0.05 changes per nucleotide position. 
Based on phenotypic characteristics and phylogenetic analyses, a novel species in a new genus, Phocaeicola abscessus gen. nov., sp. nov., is proposed.

\section{Description of Phocaeicola gen. nov.}

Phocaeicola (Pho.cae.i.co'la. L. n. Phocaea a maritime town of Ionia, modern-day Foça in Turkey; L. suff. -cola inhabitant, dweller; N.L. masc. n. Phocaeicola an inhabitant of Phocaea).

Cells are Gram-negative, strictly anaerobic, non-sporeforming, motile coccobacilli with lophotrichous flagella arrangement. Catalase- and oxidase-negative. Susceptible to bile. Asaccharolytic and non-pigmented. Member of the order 'Bacteroidales'. The type species is Phocaeicola abscessus.

\section{Description of Phocaeicola abscessus sp. nov.}

Phocaeicola abscessus (abs.ces'sus. L. gen. n. abscessus of an abscess).

Displays the following properties in addition to those given in the genus description. After 7 days growth in Schaedler broth, $7 \%$ cells are rods $(1.7-0.4 \mu \mathrm{m}$ wide and $1.2-6.5 \mu \mathrm{m}$ long) and $93 \%$ cells are coccoid $(0.3-0.6 \mu \mathrm{m}$ wide and $0.4-$ $0.9 \mu \mathrm{m}$ long). The optimum temperature for growth is $37{ }^{\circ} \mathrm{C}$. After 7 days growth on chocolate agar, colonies are white, entire, circular, regular, smooth, shiny, convex and $1 \mathrm{~mm}$ in diameter. Using API ZYM, alkaline phosphatase, acid phosphatase, naphthol-AS-BI-phosphohydrolase, $\alpha$ galactosidase, $\beta$-galactosidase, $N$-acetyl- $\beta$-glucosaminidase and $\alpha$-fucosidase activities are detected. Leucine arylamidase and $\alpha$-glucosidase activities are weakly positive. Esterase (C4), esterase lipase (C8), lipase (C14), valine arylamidase, cystine arylamidase, trypsin, $\alpha$-chymotrypsin, $\beta$-glucuronidase, $\beta$-glucosidase and $\alpha$-mannosidase activities are not detected. Using API Rapid ID 32A, positive reactions are obtained for $\alpha$-galactosidase, $\beta$-galactosidase, $\beta$-galactosidase 6-phosphate, $\alpha$-glucosidase (weakly positive with API ZYM), $N$-acetyl- $\beta$-glucosaminidase, alkaline phosphatase, leucyl glycine arylamidase and alanine arylamidase. Weakly positive reactions are obtained for $\beta$-glucosidase, $\alpha$-arabinosidase, arginine arylamidase and leucine arylamidase. Negative reactions are obtained for urease, arginine dihydrolase, $\beta$-glucuronidase, mannose and raffinose fermentation, glutamic acid decarboxylase, reduction of nitrate, indole production, proline arylamidase, phenylalanine arylamidase, pyroglutamic arylamidase, tyrosine arylamidase, glycine arylamidase, histidine arylamidase, glutamyl glutamic acid arylamidase and serine arylamidase. Using API $50 \mathrm{CH}$, all reactions are negative. Using the Biolog AN system, positive for utilization of dextrin, D-glucose 6-phosphate, D-malic acid, pyruvic acid, pyruvic acid methyl ester, succinamic acid, succinic acid, succinic acid monomethyl ester, L-alanyl-L-glutamine, Lglutamic acid, L-glutamine and glycyl L-glutamine, weakly positive for utilization of L-fucose, $\alpha$-D-glucose 1-phos- phate and trehalose and negative for utilization of $\mathrm{N}$ acetyl-D-galactosamine, $\mathrm{N}$-acetyl-D-glucosamine, $\mathrm{N}$-acetyl$\beta$-D-mannosamine, adonitol, amygdalin, D-arabitol, arbutin, cellobiose, $\alpha$-cyclodextrin, $\beta$-cyclodextrin, dulcitol, $i$ erythritol, D-fructose, D-galactose, D-galacturonic acid, gentiobiose, D-gluconic acid, D-glucosaminic acid, $\alpha$-Dglucose, glycerol, DL- $\alpha$-glycerol phosphate, myo-inositol, $\alpha$ lactose, lactulose, maltose, maltotriose, D-mannitol, Dmannose, melezitose, melibiose, 3-methyl-D-glucose, methyl $\alpha$-D-galactoside, methyl $\beta$-D-galactoside, methyl $\alpha$ D-glucoside, methyl $\beta$-D-glucoside, palatinose, raffinose, Lrhamnose, salicin, D-sorbitol, stachyose, sucrose, turanose, acetic acid, formic acid, fumaric acid, glyoxylic acid, $\alpha-$ hydroxybutyric acid, $\beta$-hydroxybutyric acid, itaconic acid, $\alpha$-ketobutyric acid, $\alpha$-ketovaleric acid, DL-lactic acid, Llactic acid, D-lactic acid methyl ester, L-malic acid, propionic acid, D-saccharic acid, $m$-tartaric acid, urocanic acid, alaninamide, L-alanine, L-alanyl L-histidine, L-alanyl L-threonine, L-asparagine, glycyl L-aspartic acid, glycyl Lmethionine, glycyl L-proline, L-methionine, L-phenylalanine, $\mathrm{L}$-serine, $\mathrm{L}$-threonine, $\mathrm{L}$-valine, $\mathrm{L}$-valine plus $\mathrm{L}$-aspartic acid, $2^{\prime}$-deoxyadenosine, inosine, thymidine, uridine, TMP and UMP. The major cellular fatty acids are anteiso- $\mathrm{C}_{15: 0}$, $\mathrm{C}_{16: 0}$, iso- $\mathrm{C}_{15: 0}$ and iso- $\mathrm{C}_{17: 0} 3-\mathrm{OH}$.

The type strain is $7401987^{\mathrm{T}}$ (=CCUG $55929^{\mathrm{T}}=$ CSUR $\mathrm{P} 22^{\mathrm{T}}=\mathrm{DSM} 21584^{\mathrm{T}}$ ), isolated from a human brain abscess sample.

\section{Acknowledgements}

We are grateful to Bernard Campagna and Nicolas Aldrovandi for their technical assistance in electronic microscopy and to Philippe Decloquement and Carine Couderc for their assistance in mass spectrometry analysis. We are grateful to Jean Euzéby for his help in naming the bacterium.

\section{References}

Aas, J. A., Paster, B. J., Stokes, L. N., Olsen, I. \& Dewhirst, F. E. (2005). Defining the normal bacterial flora of the oral cavity. J Clin Microbiol 43, 5721-5732.

Eckburg, P. B., Bik, E. M., Bernstein, C. N., Purdom, E., Dethlefsen, L., Sargent, M., Gill, S. R., Nelson, K. E. \& Relman, D. A. (2005). Diversity of the human intestinal microbial flora. Science 308, 1635-1638.

Fredricks, D. N., Fiedler, T. L. \& Marrazzo, J. M. (2005). Molecular identification of bacteria associated with bacterial vaginosis. $N$ Engl J Med 353, 1899-1911.

Hall, T. A. (1999). BioEdit: a user-friendly biological sequence alignment editor and analysis program for Windows 95/98/NT. Nucleic Acids Symp Ser 41, 95-98.

Hayashi, H., Sakamoto, M. \& Benno, Y. (2002). Phylogenetic analysis of the human gut microbiota using 16S rDNA clone libraries and strictly anaerobic culture-based methods. Microbiol Immunol 46, 535548.

Hofstad, T., Olsen, I., Eribe, E. R., Falsen, E., Collins, M. D. \& Lawson, P. A. (2000). Dysgonomonas gen. nov. to accommodate Dysgonomonas gadei sp. nov., an organism isolated from a human gall bladder, and 
Dysgonomonas capnocytophagoides (formerly CDC group DF-3). Int J Syst Evol Microbiol 50, 2189-2195.

Hooper, L. V. \& Gordon, J. I. (2001). Commensal host-bacterial relationships in the gut. Science 292, 1115-1118.

Kimura, M. (1980). A simple method for estimating evolutionary rates of base substitutions through comparative studies of nucleotide sequences. J Mol Evol 16, 111-120.

Saito, D., Leonardo, R. T., Rodrigues, J. L., Tsai, S. M., Höfling, J. F. \& Gonçalves, R. B. (2006). Identification of bacteria in endodontic infections by sequence analysis of $16 \mathrm{~S}$ rDNA clone libraries. J Med Microbiol 55, 101-107.

Saitou, N. \& Nei, M. (1987). The neighbor-joining method: a new method for reconstructing phylogenetic trees. Mol Biol Evol 4, 406-425.

Sakamoto, M. \& Benno, Y. (2006). Reclassification of Bacteroides distasonis, Bacteroides goldsteinii and Bacteroides merdae as Parabacteroides distasonis gen. nov., comb. nov., Parabacteroides goldsteinii comb. nov. and Parabacteroides merdae comb. nov. Int J Syst Evol Microbiol 56, 1599-1605.

Sakamoto, M., Suzuki, M., Umeda, M., Ishikawa, I. \& Benno, Y. (2002). Reclassification of Bacteroides forsythus (Tanner et al. 1986) as Tannerella forsythensis corrig., gen. nov., comb. nov. Int J Syst Evol Microbiol 52, 841-849.

Shah, H. N. \& Collins, M. D. (1988). Proposal for reclassification of Bacteroides asaccharolyticus, Bacteroides gingivalis, and Bacteroides endodontalis in a new genus, Porphyromonas. Int J Syst Bacteriol 38, 128-131.

Shah, H. N. \& Collins, M. D. (1989). Proposal to restrict the genus Bacteroides (Castellani and Chalmers) to Bacteroides fragilis and closely related species. Int J Syst Bacteriol 39, 85-87.

Shah, H. N. \& Collins, D. M. (1990). Prevotella, a new genus to include Bacteroides melaninogenicus and related species formerly classified in the genus Bacteroides. Int J Syst Bacteriol 40, 205-208.

Tamura, K., Dudley, J., Nei, M. \& Kumar, S. (2007). MEGA4: molecular evolutionary genetics analysis (MEGA) software version 4.0. Mol Biol Evol 24, 1596-1599.

Weisburg, W. G., Barns, S. M., Pelletier, D. A. \& Lane, D. J. (1991). $16 \mathrm{~S}$ ribosomal DNA amplification for phylogenetic study. J Bacteriol 173, 697-703.

Willems, A. \& Collins, M. D. (1995a). 16S rRNA gene similarities indicate that Hallella seregens (Moore and Moore) and Mitsuokella dentalis (Haapasalo et al.) are genealogically highly related and are members of the genus Prevotella: emended description of the genus Prevotella (Shah and Collins) and description of Prevotella dentalis comb. nov. Int J Syst Bacteriol 45, 832-836.

Willems, A. \& Collins, M. D. (1995b). Reclassification of Oribaculum catoniae (Moore and Moore 1994) as Porphyromonas catoniae comb. nov. and emendation of the genus Porphyromonas. Int J Syst Bacteriol $45,578-581$. 